\title{
Application of alkaline Pulping to Pruned Branches of Citrus limon from Sudan
}

Tarig Khider ( $\square$ tarigosmankhider@gmail.com )

University of Bahri https://orcid.org/0000-0003-4494-8402

Safaa Hassan Omer

University of Bahri

Osman Taha Elzaki

National Centre for Research

Salaheldin Dafalla Mohieldin

National Centre for Research

Suhair Kamal Shomeina

National Centre for Research

\section{Research article}

Keywords: Cirtus limon, Pruned branches, Physical properties, Chemical composition, Alkaline cooking, Guar gum, Anthraquinone

Posted Date: January 20th, 2020

DOI: https://doi.org/10.21203/rs.2.21218/v1

License: (c) (i) This work is licensed under a Creative Commons Attribution 4.0 International License. Read Full License

Version of Record: A version of this preprint was published at Walailak Journal of Science and Technology (WJST) on March 23rd, 2021. See the published version at https://doi.org/10.48048/wjst.2021.9409. 


\section{Abstract}

The aim of this study to utilize the pruned branches of Citrus limon in pulping with alkaline pulping methods and to determine the suitability of guar gum to improve the strength properties of pulps. The physical properties of these branches exhibited high medium density and very low percentages of bark to wood ratio. The whole chemical components of these raw materials indicated the suitability to pulp with alkaline cooking methods. Alkaline sulfite anthrquinone with methanol methods gave very good screened yield (60.1\%), negligible rejects and bleachable Kappa number 19.5 and best strength properties especially tensile and strengths. Alkaline sulfite with anthraquinone gave very good screened yield with small percentage of rejects and bleachable Kappa number. On the other hand soda cooking produced pulps with acceptable yield (41.9\%), rejects (3\%) and suitable strengths. The soda anthraquinone pulping methods produced pulp with good yields (56-59.7\%). It is obvious the effect of anthraquinone in preserving carbohydrates specifically hemicelluloses which increase the yields and strengths. Guar gum improved the physical properties of pulps when added during beating with (0.25\% on oven dry Soda-AQ pulps) It clear the suitability of Citrus limon branches with age of two years in cooking with all alkaline pulping methods applied.

\section{Introduction}

Lemon names in different languages more or less similar with scientific name Citrus limon Burm family Rutaceae [1]. The origin of lemon is Central Asia, Himalayan Mountains and northern Myanmar [2].The known countries for production of lemon around the world are, Argentina, Mexico, Italy, Brazil, Spain, China, India, United States, Turkey and Iran[3]. Lemon has medicinal properties as reduction of Joints inflammation [4] antioxidant and alcohol liver injury treatment [5] contain essential oils [6] suppression of N-nitrosamine formation [7] source of vitamin C[8] and flavor for food [9].

The dead branches of lemon tree are removed periodically to improve the growth conditions and fruit quality this process called pruning [10-14]. The dead branches usually become wastes especially in developing countries and mostly burned. The rational utilization of these dead branches will has added value for planting of lemon trees. The pulping of the branches of lemon could be considered as smart option for maximum utilization of this tree. Soda pulping of citrus branches gave high yield when anthraquinone applied during cooking [15]. The addition of guar gum during refining to improve the physical properties of pulps could consider as attractive option. Guar gum produced from seed of Cyamopsis tetragonoloba a gel-forming galactomannan [16-18]. Guar gum characterized with swelling property form good hydrogen bond within water and fibers [19].

The present work aimed to evaluate the characteristics of Citrus Limon dead branches in terms of physical properties, chemical composition, alkaline pulping and papermaking characteristics with soda with and without anthraquinone, AS-AQ and ASAM cooking methods and study the applicability of guar gum to improve the strength properties of pulps.

\section{Materials And Methods}

Nineteen dead branches were collected from two years old Citrus Limon trees after pruning, randomly selected according to TAPPI standards [20], the trees were grown in farms northern Khartoum State. The branches were transported to National Centre for Research in Khartoum, cleaned, cross cut and sawn into discs about $2.5 \mathrm{~cm}$. The bark-to-wood ratio was determined as a proportion of the branches (including bark) both by volume and by mass. The basic density was measured as the oven-dry mass/green volume of the test specimens according to British Standards [21] and (TAPPI-258 Om-02).

Chips for pulping trials were manually prepared left for drying according to TAPPI standard (T 257-cm-02) Fig. 1. A composite sample of chips was ground in a star mill, sieved with 40 by 60 mesh fractions and used for the chemical analysis. The chemical analysis was carried out in accordance with the standard methods of TAPPI standards [20], preparation for chemical analysis (TAPPI-264-cm-97) sampling and testing for moisture (TAPPI-210cm-93) hot water soluble (TAPPI-T- 207), solvent extraction of wood (TAPPI-204), Pentosans (TAPPI-223-cm-01) alpha cellulose (TAPPI-203 OS-61),and ash (TAPPI-212) lignin (TAPPI-222), except for the cellulose which was measured according to the Kurshner and Hoffer method [22]. Pulping was carried out in a 7-litre capacity rotating autoclave (Fig. 2) at a maximum temperature of 170 and $175^{\circ} \mathrm{C}$ for 2 hours.

The Lemon chips (Table 1) were cooked at different chemical charges of soda and soda-AQ 12-15\% (as $\mathrm{NaOH}$ ), $17 \%$ for $\mathrm{AS}-\mathrm{AQ}$ and $\mathrm{ASAM}$ with ratio $\mathrm{Na} \mathrm{SO}_{3}$ to $\mathrm{NAOH}$ ratio 70: 30 . The anthraquinone (AQ) was added in $0.05 \%$. The methanol was added during ASAM pulping according to [23]. A wood to liquor ratio of $1: 4$ was used [24 and 25].

Kappa number was done with TAPPI standards T236 om-99. After pulping, the cooked and screened material (Fig. 3) was cleaned with water to remove black liquor, disintegrated at $1200 \mathrm{rpm}$ for $30 \mathrm{~min}$, at room temperature. The pulp was then refined with Valley beater according to TAPPI200-sp-01 freeness of pulp (Canadian standard method TAPPI 227om-99), physical testing of pulp sheets (TAPPI-220-sp-01). Conditioning of testing atmosphere (TAPPI-402-sp-98), Burst strength (TAPPI403om-97), Tensile (TAPP-404-cm-92), grammage (TAPPI-410-om-98), thickness (TAPPI-411-om-97) and ISO standards [26]. The guar gum was added to pulp during beating of soda-AQ pulps with very small amount ( $0.25 \%$ on oven dry pulp).

\section{Results And Discussion}

Pruned branches of Citrus limon 2 years old had moderately high average basic density $572.1 \mathrm{~kg} \mathrm{~m}^{-3}$ and green density $577.3 \mathrm{~kg} \mathrm{~m} \mathrm{~m}^{-3}$ ( Table 2 ) according to Bin (1970) classification[27],Citrus linon fall within the range for commercial pulp wood (350-650 Kg m-3) according to [28]. The yield of pulp per unit volume is directly related to basic density as Citrus limon chips expected to occupy normal digester space for given pulp making capacity. The wood density is highly related to cell wall thickness and corresponding to collapsibility and conformability of the fiber. Fibers of moderately density are less flexible, however the wood of moderately high density is expected to give moderate to high yield with good quality paper. The average bark- to wood ratio by mass and volume (Table 2) were low (6.7 and 5.2\% respectively) for pulp woods. It is well known the presence of bark and dirt influences the quality of pulp, the presence of bark in low ratios affects positively on economic value of the pulp production by decreasing the cost of transportation and debarking processes.

Page 2/6 
The moderate ash content of Citrus limon (Table 3) may be attributed to the rapid growth, as the result for need of macronutrients in metabolic activities in first years. Silica content was more or less negligible. Solubility of hot water, alcohol and alcohol: cyclo hexane(1:2) were low indicting low extractives in Citrus limon wood with high solubility of $1 \% \mathrm{NaoH}$ indicated normal cooking without pretreatments and normal chemicals amounts to be used with high screened yields to be expected. However the normal Kurschner- Hoffer cellulose and high pentosans indicated good yield could be expected. On the other hand the moderate lignin content and high $1 \% \mathrm{NaOH}(18.9 \%)$ as shown in Table 3, which favorable for moderate active alkali charge. The high amount pentosans indicted easy beating and fiber-fiber bonding, however the low total extractives indicted that there will be no pitch problems and easy cooking.

Pulping of pruned branches of citrus limon was carried under four chemical processes namely Soda, soda-AQ, alkaline sulphite anthraquinone (AS-AQ) and alkaline sulphite anthraquinone with methanol ASAM. Optimization of delignification and results of yields were given in Table 4.

The active alkali charges for the four processes were in range (12-17\%) with more or less similar cooking conditions. The slight differences in time to reach the needed for maximum temperatures applied to AS-AQ and ASAM methods which were increased with 10 min. It seemed the addition of anthraquinone to Soda, AS-AQ and ASAM trials and lately methanol to ASAM cooking accelerated the delignification and preserved the carbohydrates ([29-34]. The contribution of AQ was supported further by addition of methanol in ASAM pulping resulted in lowest Kappa number 19.5 compared to other three methods (Table 4). The pulping results for branches of Citrus limon (Table 4) show that, this raw material is easy to delignify. With all processes applied, bleachable kappa numbers (19.5-26.3) could be reached at good to excellent screened yields (41.9-60.1\%). ASAM pulping resulted in highest screened yield (60.1\%) with negligible amount of rejects $(0.2 \%)$ at bleachable pulp had low kappa number 19.5 .

Comparison of strength properties of different Citrus limon unbleached pulps (Table 4), indicated in general the high tensile strength of the ASAM pulps. The high tensile strength, which mainly based on the good bonding ability of the fibers, results from the high carbohydrate content of ASAM pulps due to the high stability of xylan and cellulose in the outer cell wall layers. However, The Soda Citrus limon pulp had lower tensile strength compared to ASAM and AS-AQ pulps which can be explained by the lower pentosan preservation during cooking. The overall evaluation of pulp properties showed the superiority of ASAM pulps in all strength properties and fluctuations in grammage and thickness, however the Soda process showed inferior results in strength properties. When gaur gum was added to Soda-AQ( CL3) dramatically increase the physical properties especially tensile and burst strengths compared with Soda-AQ (CL2)

\section{Conclusion}

On the basis of the physical and chemical properties, the pruned branches of Citrus limon could be considered as a medium high pulp woods. The cooking of Citrus limon branches with alkaline processes indicated its suitability for production of pulp and paper. Soda and Soda - AQ methods can be cooked to bleachable Kappa numbers for bleachable pulps. In ASAM pulping, the effect of anthraquinone and methanol was clearly remarkable, total yield, screened yield bleachable Kappa numbers with both AS-AQ and specifically ASAM process with good to excellent pulp properties.

The rational utlization of citrus limon prouned branches as in production of pulp and paper instead of being waste could be economically and envrionementally atteactive with need for fessebility studies for complement the techanical studies.

\section{Abbreviations}

\section{TAPPI}

Technical Association of the Pulp and Paper Industry.

ASAM

Alkaline sulfite anthraquinone with methanol pulping method

AS-AQ

Alkaline sulfite with anthraquinone pulping method

AQ

Anthraquinone

\section{Declaration}

\section{Acknowledgements}

Authors grateful for Students from University of Bahri, college of Applied and Industrial Sciences, department of Pulp and Paper who did work lab, Najwa Ahmed Abdelkareem, Elhadi Abduelmageed Mohammod and Eltaib Adam Edrees.

\section{Funding}

Not applicable.

\section{Availability of data and materials}

We have already included most of data in the manuscript, the lab and data, some data not included in the manuscript attached as Additional file 1.

\section{Authors' contributions}

SHO and SKS were carried out, supervised the chemical analysis, soda-AQ pulping and revised the draft manuscript. OTE did the Soda pulping and their analysis, review the draft manuscript, SDM supervised and carried out the evaluation of paper properties and revised the draft manuscript. TOK wrote the draft manuscript, designed the study and supervised the work carried out AS-AQ and ASAM cooking. All authors read and approved the final manuscript. 


\section{Ethics approval}

Not applicable.

\section{Consent for publication}

Not applicable.

\section{Competing interests}

The authors declare that they have no competing interests

\section{References}

1. Noura S. Dosoky and William N. Setzer 2018. Biological Activities and Safety of Citrus spp. Essential Oils. International Journal of Molecular Sciences. 25 pages http://dx.doi.org/10.3390/ijms19071966

2. Tong Zhou, Yu-Jie Zhang, Dong-Ping Xu, Fang Wang,1 Yue Zhou, Jie Zheng, Ya Li, Jiao-Jiao Zhang, and Hua-Bin Li 2017. Protective Effects of Lemon Juice on Alcohol-Induced Liver Injury in Mice. BioMed Research International :8 pages https://doi.org/10.1155/2017/7463571

3. Mahendra Pal. 2017. Lemon: A Versatile Fruit of Multiple Uses. Agricultural World:1-3 https://www.researchgate.net/publication/318360553_Lemon_A_Versatile_Fruit_of_Multiple_Uses

4. Mohanapriya, M. Lalitha Ramaswamy and Rajendran, R. 2013. Health and Medicinal Properties of Lemon Citrus Limonum International journal of ayurvedic \& herbal medicine 3(1):1095-1100 http://interscience.org.uk/index.php/ijahm

5. Loredana Abbate, Francesco Mercati, Sergio Fatta Del Bosco 2019. An Overview on Citrus Mal Secco Disease: Approaches and Strategies to Select Tolerant Genotypes in C. limon Crop Breeding, Genetics and Genomics 1-29. https://doi.org/10.20900/cbgg20190018

6. Jonathan H. Crane 2019 Lemon Growing in the Florida Home Landscape Horticultural Sciences UF/IFAS Extension 1-12 https://edis.ifas.ufl.edu/pdffiles/HS/HS40200.pdfDepartment

7. Shafiya Rafiqa Raj kumara KaulaS.A. Sofia Nadia Bashira Fiza Nazirb Gulzar Ahmad Nayikc 2018. Citrus peel as a source of functional ingredient: A review. Journal of the Saudi Society of Agricultural Sciences.17 (4), : 351-358 https://doi.org/10.1016/j.jssas.2016.07.006

8. Alexander Shula Kefi, Chrisanty Chama, Lumbwe Kalumba, lan Bbole Patience Chungu, Majorie Mbambara.2016. Vitamin C Levels in Lemons (Citrus Limon) Grown in Zambia; an Opportunity for Utilization in Fish Feeds. Journal of Agriculture and Life ScienceA:37-42.

https://www.researchgate.net/publication/309762501_Vitamin_C_Levels_in_Lemons_Citrus_Limon_Grown_in_Zambia_an_Opportunity_for_Utilisation_in_I

9. Maria G Veldhuizen, Ashik Siddique, Sage Rosenthal, Lawrence E Marks 2018. Interactions of Lemon, Sucrose and Citric Acid in Enhancing Citrus, Sweet and Sour Flavors. Chemical Senses, Vo 43 (1): 17-26. https://doi.org/10.1093/chemse/bjx063

10. P.H. Tucker, T.A. Wheaton and R.P. Muraro 1994. Citrus Tree Pruning Principles and Practices Fact Sheet HS-144 https://counties.agrilife.org/harris/files/2011/05/Citrus-Pruning.pdf

11. Intrigliolo, F.. Roccuzzo. G. 2011 Modern trends of Citrus pruning in Italy Hort. Sci., 25(3): 187-192 DOI: 10.13128/ahs-12768

12. Bernardo Martin-Gorriz Ignacio Porras Castillo and Antonio Torregrosa 2014 Effect of mechanical pruning on the yield and quality of 'Fortune' Spanish Journal of Agricultural Research 12(4): 952-959 http://dx.doi.org/10.5424/sjar/2014124-5795

13. Surendra Rajaram Patil , Santosh Madhukar Bichkule and Arvind Munjajirao Sonkamble 2018 Effect of Severity and Time of Pruning on Growth, Flowering and Fruit Set of Hasta Bahar in Acid Lime International Journal of Current Microbiology and Applied Sciences Special Issue-6 pp https://www.ijcmas.com/special/6/Surendra\%20Rajaram\%20Patil,\%20et\%20al.pdf

14. J. Krajewskia and S.A. Krajewski 2011. Canopy Management of Sweet Orange, Grapefruit, Lemon, Lime and Mandarin Trees in the Tropics: Principles, Practices and Commercial Experiences Acta Hort. 894, ISHS 65-76 https://swfrec.ifas.ufl.edu/hlb/database/pdf/00002843.pdf

15. Ahmet TUTUSMustafa CICEKLER Nazmiye KUCUKBEY 2016. Pulp and Paper Production from Bitter Orange (Citrus aurantium L.) Woods with Soda-AQ Method Kastamonu Uni., Orman Fakültesi Dergisi, 16 (1): 14-18 DOI: 10.17475/kujff.29775

16. Deepak Mudgil Sheweta Barak Bhupendar Singh Khatka 2011. Guar gum: processing, properties and foodapplications-A Review J. Food Sci. Technol. DOI: $10.1007 / \mathrm{s} 13197-011-0522-x$

17. Seon-Joo Yoon, Djong-Chi Chu , and Lekh Raj Juneja 2008. Chemical and Physical Properties, Safety and Ap https://pdfs.semanticscholar.org/25c3/9cbf566c7a51f488648adf9d42862f1e2c74

18. Karen Yu David Wong Jagdish Parasrampuria David Friend 1996. Guar Gum Analytical Profiles of Drug Substances and Excipients 24 : $243-276$ https://doi.org/10.1016/S0099-5428(08)60695-4

19. D. Bradley, A. Ball, S. E. Harding \& J. R. Mitchell 1989. Thermal Degradation of Guar Gum Carbohydrate Polymers $10: 205-214$ https://www.nottingham.ac.uk/ncmh/documents/papers/paper55.pdf

20. TAPP1, 2002. Standards and suggested methods. TAPPI, New York https://www.tappi.org/globalassets/documents/standards/tm_guidelines_complete.pdf

21. British Standards B.S. 373.1957. The British Standard Methods of Testing Small Clear Specimens of Timber. British Standards Institute, London. https://www.document-center.com/standards/show/BS-373 
22. Obolenskaya, A.V., V.P. Tshegolov, G.I., Akim, N.C., Kossoviz, N. L., Emelyannova, I.Z. 1965. Practitcheshie Raboti po Himii Drevesinii Tzellulozi. Moscow, Lesporm. (In Russian)

23. Kordsachia, O. Wandianger, B. and Patt, R. 1992. Some Investigation on ASAM pulping and chlorine free bleaching of Eucalyptus from Spain. Holz Roh. Werkst. 50: 85- 91 http://agris.fao.org/agris-search/search.do?recordID=DE19920076161

24. Holton, H., 1977. Soda additives softwood pulping a major new process. Pulp Paper Can., 78: T218-T223 http://agris.fao.org/agris-search/search.do? recordID =US201301254810

25. Khristova, P. Gabir, S Bentcheva, S. Khider, T.(1998). Soda-AQ pulping of four Acacias from Sudan. Cellulose Chemistry and Technology 32 (3-4), $299-307$ https://www.researchgate.net/publication/216021309_Soda-AQ_pulping_of_four_Acacias_from_Sudan

26. ISO standards 2003. International Organization for Standardization. https://www.iso.org/committee/45674/x/catalogue/

27. Bin, P.T. 1970. Present status of pulping and papermaking research with special reference to possible utilization of tropical hardwoods. Proc. PanMalaysian Forestry Conference Malaysia

28. Casey, J1980.Pulp and Paper Chemistry and Chemical Technology Vol. 1. 2nd New York. Interscience Publications. https://www.amazon.com/Pulp-PaperChemistry-Chemical-Technology/dp/0471031755

29. Khristova, P. Kordsachia, O. Khider, T (2005). Alkaline pulping with additives of date palm rachis and leaves from Sudan. Bioresource technology 96 (1), 79-85 https://doi.org/10.1016/j.biortech.2003.05.005

30. Safaa Hassan Omer, Tarig Osman Khider, Osman Taha Elzaki, Salaheldin Dafalla Mohieldin and Suhair Kamal Shomeina 2019. Application of soda-AQ pulping to agricultural waste (okra stalks) from Sudan .BMC Chemical Engineering 1:6 https://doi.org/10.1186/s42480-019-0005-9

31. Khider, T.O., Elzaki, O.T., and Omer, S.H. (2011). Soda and soda-AQ pulping of Albizia bebbeck from Sudan. Suranaree J. Sci. Technol., 18(4):299-30. https://www.researchgate.net/publication

32. Khider, T. O., Omer, S.H., and Elzaki, O.T. (2012). Pulping and Totally Chlorine Free (TCF) Bleaching of Acacia mellifera from Sudan. World Appl. Sci. J., 16(9):12561261. https://www.researchgate.net/publication

33. Masrol, S.R. Ibrahim, M.H.I. Adnan, S. Talib, M.R. and Sian, L. (2017). Effect of Soda-Athraqunione Pulping Variables on Durian Rind Pulp and Paper Characteristics: A preliminary Test. Materials Science and Engineering 226: IOP Publishing. doi:10.1088/1757-899X/226/1/012175

34. Jahan, M. Sarwar, Sarkar, M and Quaiyyum, M.A. (2018). Pulping of Gamarri root (Gmelina arborea) Journal of the Indian Academy of Wood Sciences. Pp 1-5 https: 11 doi.org/10. 10071s13196-018-0204-7

\section{Tables}

Due to technical limitations, Tables 1-4 are provided in the Supplementary Files section.

\section{Figures}

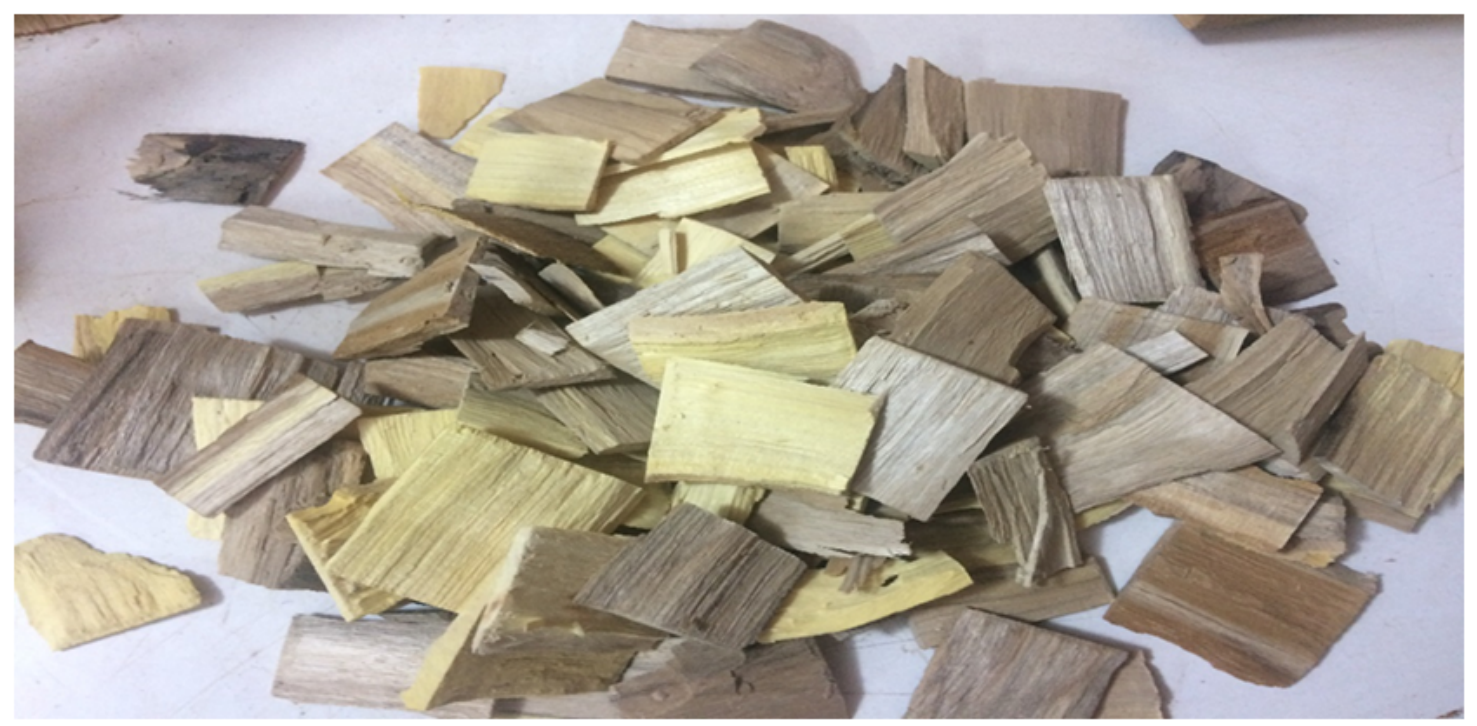

\section{Figure 1}

The chips of Citrus Limon after drying 


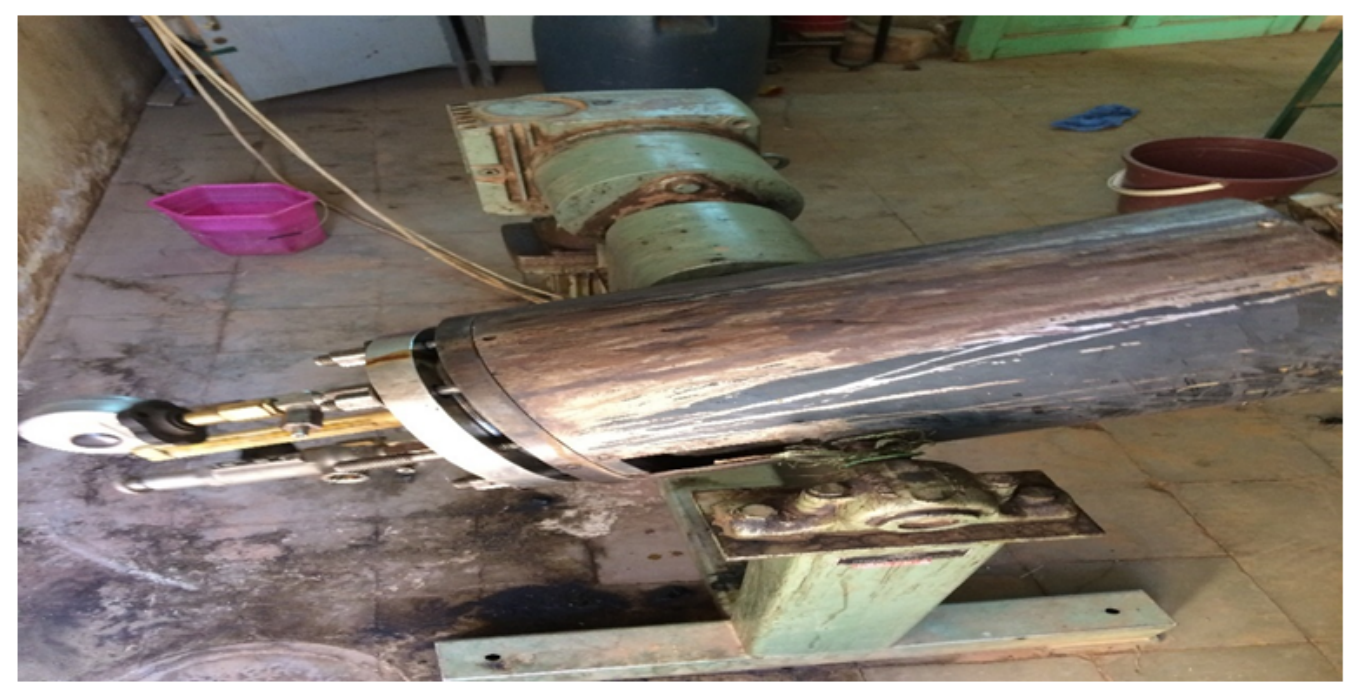

\section{Figure 2}

The digester used during pulping of Citrus Limon with Soda, soda-AQ, AS-AQ and ASAM methods

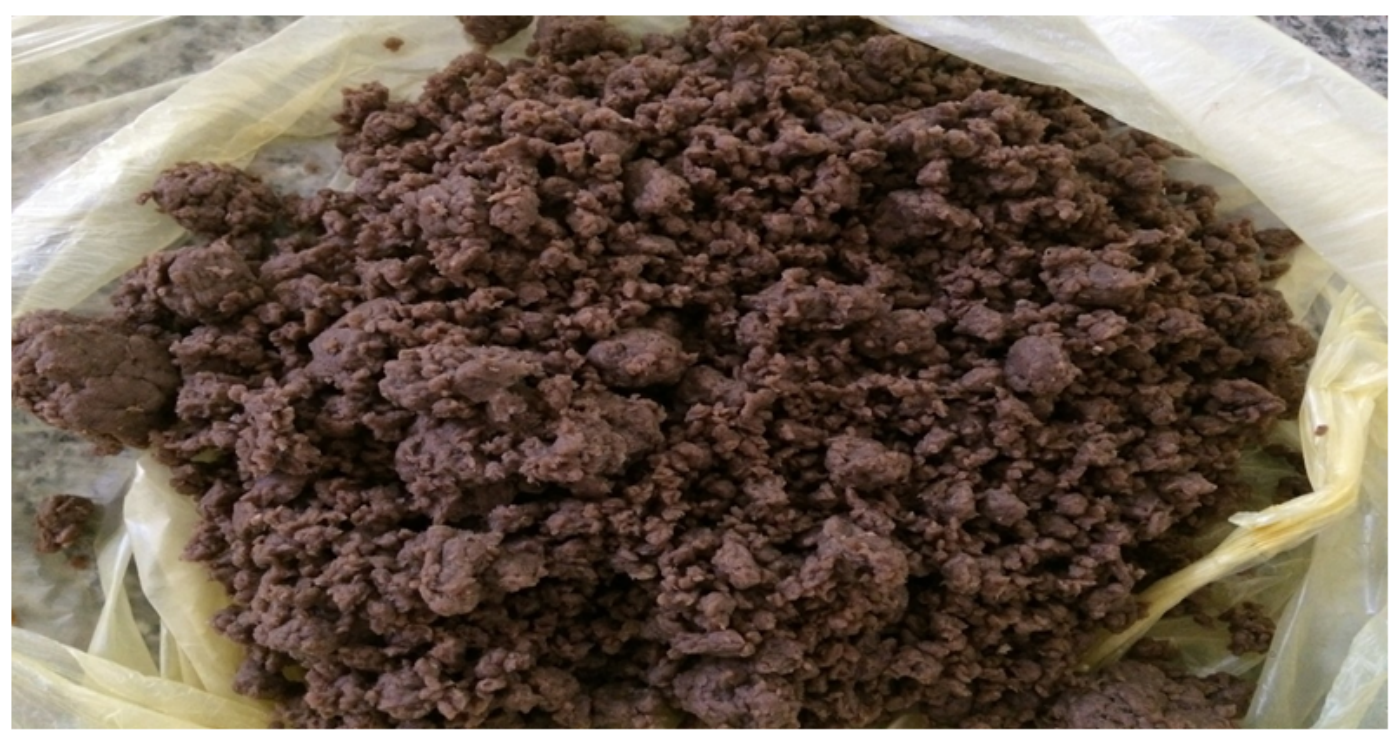

Figure 3

Screened pulps of Citrus limon cooked with soda cooking.

\section{Supplementary Files}

This is a list of supplementary files associated with this preprint. Click to download.

- Tables.docx

- SupplementaryFiles.doc 